\title{
Experimental Investigation on Mineral Content of Fly Bottom Ash and Strength Characteristics of Fly Bottom Ash Bricks - A Review
}

\author{
Arunkumar. G, Jai Kumaresh. B, Arokia Jerome. D, Parameswaran. P, Rajkumar. T \\ Department of Mechanical Engineering, K Ramakrishnan College of Technology, \\ Samayapuram, Tiruchirappalli, Tamil Nadu, India
}

\begin{abstract}
This investigation is to study the mineral contents of fly-bottom ash. After many years of research in sustainable construction materials, the quality of producing construction materials has significantly improved. And the replacement of ordinary cement with fly-bottom ash has showed several improvements such as strength and other characteristics. During the production of ordinary cement, $\mathrm{CO} 2$ emissions are very high and energy consumption is also very high. Due to limited resources of nature, it has to be reconsidered to use the ordinary cement. The advancement of technologies has led to significantly promote the use of fly-bottom ash in ordinary cement in order to improve the quality of construction materials. The fly ash is been used for zeolite synthesis, synthetization of organic geo-polymer and in manufacturing of construction materials.
\end{abstract}

KEY WORDS: sustainable; zeolite synthesis; geopolymer

\section{INTRODUCTION}

Rising population, urbanization and industrial revolution has significantly improved the production of solid waste and other wastes. Waste management is worldwide phenomenon. India produces about 40 million tones of solid waste every year. In our day to day life the collection of waste very tedious process and disposal of municipal solid waste is a great problem of urban life. The proper disposal of urban waste is necessary for the preservation of natural resources and development of environment. One of the major solid waste of Thermal power plant is fly ash. By mixing the fly ash with concrete during construction there will be significant reduction in production of solid waste and green house gas such as $\mathrm{CO}_{2}$. Concrete is the most widely used construction material in the world. The green house gases produced during production of cement will cause serious environmental contamination such as smog and acid rain and harmful effects to living beings also. Mostly the fly-bottom ash is dumped in landfills which could cause potential damage to aquifers and ground water reserves. Studies showed many alternative methods for effective solid waste management and improved methods of producing construction materials. Along with Fly-bottom ash many natural organic materials are added to improve the strength characteristics of the construction materials.

The other replacements for ordinary cement are fly ash, bottom ash, silica fume, risk husk ash, and Metakaolin etc., through years furthermore researches have been carried out.

\section{Geo-polymer}

Geo-polymers are either organic or inorganic materials with are formed by repeating units of chemical compounds.

\subsection{Geo-polymerization}

It is the process of combining the chains of monomers to form a covalently bonded network.

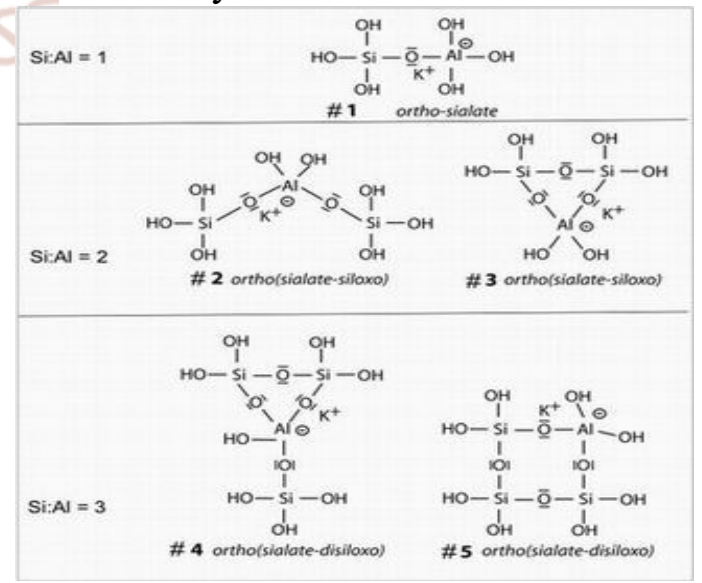

Figure 1.1 
The above figure 1.1 shows 5 soluble oligomers which are the actual starting units of potassium-based alumino-silicate geo-polymerization.

\subsection{Geo-polymer cement}

It is a new type of concrete which utilizes only a small portion of ordinary cement as a binder, binding characteristics are based upon the reaction of an alkaline liquid with organic materials which are rich in silica and alumina.

\subsection{Materials used in geopolymer concrete}

2.3.1 Blast-furnace slag is a non-metallic fine powder material consists of silica and alumina essential for geopolymer synthesization, it is a byproduct of iron and steel industry. It has the ability to improve the durability of the concrete so it has been widely used across the world.

2.3.2 Metakaolin is formed by heating china clay (kaolinite) between the range of $650^{\circ} \mathrm{c}-850^{\circ} \mathrm{c}$. It is basically used to improve the binding property of concrete.

2.3.4 Alkaline Solutions, solutions which have $\mathrm{PH}$ value more than 7 are alkaline solutions these are used in many day to day applications. Some examples potassium hydroxide and sodium hydroxide etc.,

\section{METHOD OF MANUFACTURING}

Ash bricks can be prepared by the use of different semi automatic and automatic machines with the use of moulds pre attached in machines, where using of manual moulds in the manufacturing method leads to frequent change in the size of the bricks and may results in the poor exterior quality of the bricks. Approximately every ash bricks manufacturing plant uses machines to produce ash bricks, which led to the use of less labours and makes the cost less of per ash bricks which can be easily afforded by low to high class families. There are 3 different proportion by which fly ash bricks can be prepared which depends on the materials available.

\subsection{PROCESS OF MANUFACTURING}

Manufacturing process is illustrated in the form of flow chart as shown in the figure 1.2. The flow demonstrates the step by step process of preparing the fly-ash bricks.

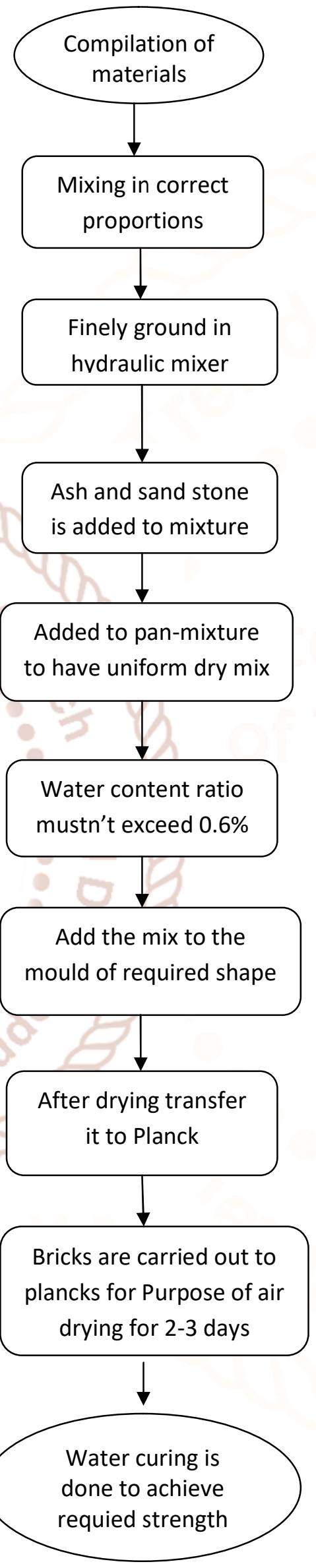

Figure 1.2 Process of manufacturing 


\section{MIXING PROPORTIONS}

Mixing proportions make a great impact on strength characteristics of fly-bottom ash bricks, so in-order to know the optimize mixing proportions various research has been done over this area, Recent conclusions are reported below in table 1.1.

Mixing proportions used in this study.

\begin{tabular}{lcccccc}
\hline Formulation & M65 & M70 & M75 & F65 & F70 & F75 \\
\hline Mechanical-bed bottom ash (wt\%) & 65 & 70 & 75 & - & - & - \\
Mechanical-bed fly ash (wt\%) & 15 & 10 & 5 & - & - & - \\
Fluidizdd-bed bottom ash (wt\%) & - & - & - & 65 & 70 & 75 \\
Fluidized-bed fly ash (wt\%) & - & - & - & 15 & 10 & 5 \\
Reservoir sediment (wt\%) & 20 & 20 & 20 & 20 & 20 & 20 \\
\hline
\end{tabular}

Table 1.1 Mixing proportions

\section{ISSUES IN WASTE MANAGEMENT}

Mr. Abhimanyu Sing (2014) has studied the waste management status \& health effects, according to his study, the random wastes in the streets which remain uncollected are increasing on a day to day basis it has to be separated as bio degradable and non biodegradable and to be sent for waste treatment.

An awareness program has to be conducted in order to increase public interest towards waste management.

\subsection{ECONOMIC BENEFITS GEOPOLYMER CONCRETE}

\section{N A Lloyd and B V Rangan (2010)}

In this study it is said that using fly ash based geopolymer as a replacement for ordinary cement is very economical in both ecological aspect and monetary terms.

Other characteristic improvement in construction materials are the low creep, resistance to sulphate attack and good acid resistance.

Finally geo-polymer concrete saves lots of money thus caused due to repairs and maintenance of those infrastructures.

\subsection{INEVITABILITY OF GEO-POLYMER CONCRETE}

Due to the growth in population and development in infrastructure globally, demand for cement as per International Cement Review's report was 3,524 million tons in 2015 which is increasing by nearly $12 \%$ annually which could result in a huge shortage on limestone in future, in addition to this emission of $\mathrm{CO}_{2}$ in the atmosphere is the major threat for climatic changes.

Vikas R Nadig et al (2015) studied the Bottom Ash as Partial Sand Replacement in Concrete. From this study physical characteristics of concrete when partially replaced with bottom ash as coarse aggregates. The implementation of Bottom ash in concrete shows a effective improvement in strength characteristics and waste management as well as resources conservation The density of Bottom Ash concrete decreases with the increase in bottom ash content, since the specific gravity of bottom ash is low as compared to fine aggregates.

A S Cadersa et al (2014) this study shows the Use of Untreated Bottom Ash as partial Replacement in Concrete. Unprocessed bottom ash is investigated for its structural characteristics in this study.

Varying compositions of bottom ash in percentage $(20 \%, 30 \%, 40 \%, 60 \%$, and $80 \%$ respectively) are experimentally investigated for its physical and chemical characteristics. The results show that increase in bottom ash content increases the blending capability. $40 \%$ replacement of bottom ash decreases characteristics such as, compressive strength, flexural strength, and modulus of elasticity. From this research it is said that $20 \%$ replacement of bottom ash is the optimum percentage also shows that $20 \%$ is the optimum percentage to achieve favorable strength.

Lokeshappa et al. (2011) has stated that the only a small portion of fly ash is utilized in construction field and the remaining is left unused and untreated. The fly ash pollute the atmosphere and water bodies. Many researches is to be done in order to utilize the industrial wastes into construction materials. Numerous research and development programs are undertaken for studying the characteristics of fly ash and to use it for better replacement for ordinary cement.

Due to this many benefits can be achieved and better replacement for ordinary cement which may significantly reduce the $\mathrm{Co}_{2}$ emission and global warming

Kumar V. et al. (2005) has estimated that the thermal power industry will produce fly ash at about 190 million tons by 2015 and 325 million tons by 2019 . 


\section{OPTIMIZATION:}

Muhammad N. S. Hadi et al (2018) this study was conducted on optimization of mixes i.e., $\mathrm{sio}_{2}$ content and amount of alkaline liquids such as $\mathrm{Na} 2 \mathrm{SiO} 3$ and $\mathrm{NaOH}$. The result shows that the increase in contents of cao and $\mathrm{Na}_{2} \mathrm{O}$ does not increase the compressive strength of fly ash bricks this led to the intervention of particle size the contents has significant effect on the strength of the bricks. The augmentation of alkaline liquids has showed some improvements in the strength characteristics up to a certain level of inclusion beyond that level the alkaline liquids increases the porosity of the bricks which in turn reduces the strength of the bricks.

\section{Christof Lanzerstorfer et al (2018) this} experimental review shows the particle size dependence on the composition of various mineral contents in the fly ash. It has been noted that decrease in particle size contrarily increase some of the minerals which contribute to the mass but heavy metals such as hg ,p ,pb etc., decrease in concentration. This phenomenon is due to the coarse particles will not mix well with the mortar. New phenomenon air classification has been applied in this study to classify metals which are independent of the particle size.

\section{Conclusion:}

From this review it has been understood that ashes from thermal power plant are rich in silica and alumina so it could be a better replacement "for ordinary cement. Due to low specific gravity the bricks produced completely with ash may not be favorable. So in order to achieve physical strength blending of ash with ordinary cement could be a great solution for industrial waste management and reducing greenhouse gases.

From further research and study A S Cadersa et al (2014) has said that $20-30 \%$ replacement of ash in concrete is the optimum value to achieve desirable qualities beyond this may disrupt the qualities of ordinary cement.

\section{Reference}

1. Jang JG, Ahn YB, Souri H, Lee HK. A novel ecofriendly porous concrete fabricated with coal ash and geopolymeric binder: Heavy metal leaching characteristics and compressive strength. Constr Build Mater 2015;79:173-81. http://dx.doi.org/10. 1016/j.conbuildmat.2015.01.058.
2. Roychand R, De Silva S, Law D, Setunge S. Micro and nano engineered high volume ultrafine fly ash cement composite with and without additives. Int J Concr Struct Mater 2016; 2016(10):113-24.

http://dx.doi.org/10.1007/s40069-015-0122-7.

3. Belviso C, Cavalcante F, Di Gennaro S, Palma A, Ragone P, Fiore S. Mobility of trace elements in fly ash and in zeolitised coal fly ash. Fuel 2015; 144:369-79.

http://dx.doi.org/10.1016/j.fuel.2014.12.037.

4. Christof Lanzerstorfer,2018, Fly ash from coal combustion: Dependence of the concentration of various elements on the particle size, School of Engineering/Environmental Sciences, University of Applied Sciences Upper Austria, Stelzhamerstraße 23, A-4600 Wels, Austria,www.elsevier.com/locate/fuel

5. P. Nath, P. Sarker, Effect of alkaline activator properties on the fly ash based geopolymer concrete for ambient curing condition, in: Concrete 2013: Proceedings of the 26th Biennial National Conference of the Concrete Institute Australia, 2013.

6. AS 1012.9: Methods of testing concreteCompressive strength tests-Concrete, mortar and grout specimens, Standards Australian International Ltd, Australia, 2014.

7. G.S. Ryu, Y.B. Lee, K.T. Koh, Y.S. Chung, The mechanical properties of fly ashbased geopolymer concrete with alkaline activators, Constr. Build. Mater. 47 (2013) 409-418.

8. D. Adak, M. Sarkar, S. Mandal, Effect of nanosilica on strength and durability of fly ash based geopolymer mortar, Constr. Build. Mater. 70 (2014) 453-459.

9. S. Zeng, J. Wang, Characterization of mechanical and electric properties of geopolymers synthesized using four locally available fly ashes, Constr. Build. Mater. 121 (2016) 386-399.

10. Arunkumar.G | Dr. P. Navaneetha Krishnan "Experimental Enhancement of Heat Transfer Analysis on Heat Pipe using $\mathrm{SiO} 2$ and $\mathrm{TiO} 2 \mathrm{Nano}$ Fluid" Published in International Journal of Trend in Scientific Research and Development (ijtsrd), ISSN: 2456-6470, Volume-2 | Issue-4, June 2018

11. Muhammad N.S. Hadi, Mustafa Al-Azzawi, Tao $\mathrm{Yu}(2018)$, School of Civil, Mining and 
International Journal of Trend in Scientific Research and Development (IJTSRD) ISSN: 2456-6470

Environmental Engineering, University of Wollongong, Australia, Effects of fly ash characteristics and alkaline activator components on compressive strength of fly ash-based geopolymer mortar

12. Navaneethakrishnan G, Selvam V, Julyes SJ. Development and mechanical studies of glass/banana fiber hybrid reinforced silica nano particles with epoxy bio-nanocomposites. J Chem Pharm Sci 2015; 7, 197-199.

13. Illinois Department of Commerce and Community Affairs, Manufacturing Commercial Bricks with Fly Ash from Illinois Coals, www.commerce.state.il.us.

14. Lingling, X., et al., Study on fired bricks with replacing clay by fly ash in high volume ratio. Construction and Building Materials. In Press, Corrected Proof.

15. Pimraksa, K., Wilhelm, M., Kochberger, M. and Wruss, W., A New Approach to the Production of Bricks Made of $100 \%$ Fly Ash, 2005 International Ash Utilization Symposium, Center for Applied Energy Research, University of Kentucky, Paper \# 84, http://www.flyash.info.

16. A Case Study on Municipal Solid Waste Management in Chandan Nagar City S K Maity1, B K Bhattacharyay2, B Bhattacharyya3,1West Bengal University of Technology 2Department of Mechanical Engineering, Bengal Engineering and Science University, Shibpur, 3Department of Production Engineering, Jadavpur University, Corresponding Author: Swapan Kumar Maity

17. A Case Study on Municipal Solid Waste Management in Solapur City, Maharashtra, India, B.L.Chavan*, N.S. Zambare**, *Department of Environmental Science, School of Earth Science, Solapur University, Solapur, India, **Department of Environmental Studies, St. Gonsalo Garcia College, Vasai, India

18. Appropriate Design and Operation of Sanitary Landfills, Hans- Günter Ramke, HöxterPrepared for the International Conference on Sustainable Economic Development and Sound Resource Management in Central Asia By Professor Dr.Ing. Hans-Günter Ramke University of Applied Sciences Ostwestfalen-Lippe, Campus Hoexter An der Wilhelmshöhe 44, D-37671 Hoexter, Phone++49/5271/687 130, e-mail hansguenter.ramke@hs-owl.de_ArvidLindell,
Achievement of sustainable solid waste management in developing countries

19. A case study of waste management in the Kavango region, Namibia, Master dissertation 2012, Environmental and Energy System Studies, Department of Technology and Society, Lund University.

20. Assessment of the status of municipal solid waste management in metro cities, state capitals, class I cities, and class II towns in India: An insight, Sunil Kumar a,*, J.K. Bhattacharyya a, A.N. Vaidya $^{\mathrm{a}}$, TapanChakrabarti ${ }^{\mathrm{a}}$, SukumarDevotta ${ }^{\mathrm{a}}$, A.B. Akolkarb, National Environmental Engineering Research Institute (NEERI), Nehru Marg, Nagpur 440 020, India, Central Pollution Control Board (CPCB), New Delhi, India.

21. Parag S. Dawane and Prof. Sagar M. Gawande Anantrao Pawar College of Engineering and Research Pune, Parvat REVIEW ARTICLE SOLID WASTE MANAGEMENT REVIEW http://www.journalcra.com,International Journal of Current Research Vol. 7, Issue, 05, pp.1601916024, May, 2015.

22. Lokeshappa B.,Dikshit Anil Kumar (2011), "Disposal and Management of Fly ash", IPCBEE, IACSIT Press, Singapore

23. Bakri Mohd Mustafa Al, "Review on fly ashbased Geopolymer concrete without Portland cement", JETR

24. International Journal of Civil \& Environmental Engineering, Selangor, Malaysia

25. Aleem A.,Arumairaj P.D.(2012), "Geopolymer Concrete-A Review", IJEST.

26. Lloyd N.A., Rangan B.V. (2010), “Geopolymer Concrete A Review of Development and Opportunities", $35^{\text {th }}$ Conference on Our World in Concrete \& Structures, Singapore.

27. A. Sumathi, K. Saravana Raja Mohan, Compressive Strength of Fly Ash Brick with Addition of Lime, Gypsum and Quarry Dust "International Journal of ChemTech Research (2014-2015).

28. Er. Rinku Kumar, Er. Naveen Hooda ,an Experimental Study on Properties of Fly Ash Bricks International Journal of Research in Aeronautical and Mechanical Engineeringe (September 2014). 
International Journal of Trend in Scientific Research and Development (IJTSRD) ISSN: 2456-6470

29. Manish Kumar Sahu, Lokesh Singh,

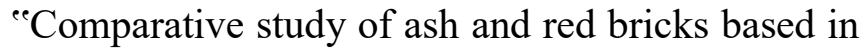
survey "International Journal of Advanced Research Methodology in Engineering \& Technology (December 2016).

30. Manish Kumar Sahu, Lokesh Singh, Suchi Nag Choudhary, "Critical review on bricks"e International Journal of Engineering and Management Research (September- October 2016).

31. S. Naganathan, N. Subramaniam and K. Nasharuddin Bin Mustapha. "Development of bricks using thermal power plant bottom ash and fly ash", Asian Journal of Civil Engineering, 2012.

32. Nutan C. Patel, Prof. Jayeshkumar Pitroda „Fly ash brick; glass fibre the innovative concept for getting higher strength bricks "International Journal of Innovative Research in Science, Engineering and Technology (March 2013).

33. M. Narmatha, R. Aruna, M. Saraswathi „Strengthening of Fly Ash Bricks by Ironite (May- Jun. 2014).

34. Ashik Kumar Parashar, Rinko Parashar," "Bricks with Total Replacement of Clay by FlyAsh Mixed with Different Materials", International Journal of Scientific and Research, July 2012.

35. M. Narmatha $\quad$ R. ArunaM. Saraswathi,,Strengthening of Fly Ash Bricks ${ }^{\text {ee }}$ by Ironite IOSR Journal of Mechanical and Civil Engineering 2014.

36. V. Selvam, P. Senthil Kumar, G. Navaneetha Krishnan, G.T. Senthil Andavan, Photocatalytic degradation of organic contaminants by gC3N4/EPDM nanocomposite film: Viable, efficient and facile recoverable,

37. Municipal solid waste management challenges and health risk problematic solutions at Agra city, U. P., India, By Abhimanyu Singh, Jamshed Zaidi, DivyaBajpai, Gunjan Sharma, AmitaYadav, Dheerendra S. Chauhan and Shree Ganesh Institute of Environment \& Development Studies, Bundelkhand University, Jhansi, India 2014.

38. Solomon Cheru, Assessment Of Municipal Solid Waste Management Service In Dessie Town, Addis Ababa University, School Of Graduate Studies, June, 2011

39. Status Report On Municipal Solid Waste
Management, Central Pollution Control Board(Ministry Of Environment \& Forests) PariveshBhawan, East ArjunNagar, Delhi - 110 032

40. Materials Science and Engineering: C, Volume 84, 2018, Pages 188-194,ISSN 0928-4931, https://doi.org/10.1016/j.msec.2017.11.039.

41. R. Praveen Kumar, G. Navaneetha Krishnan, V. Venkadesh, N. Premkumar, "Dual Side Water Pumping System using Scotch Yoke Mechanism", Indian Journal of Science and Technology, vol. 8, no. 36, 2015.

42. Ismail I, Bernal SA, Provis JL, Hamdan S, van Deventer JSJ. Micro structural changes in alkali activated fly ash/slag geopolymers with sulphate exposure. Mater Struct 2013; 46:361-73.

43. Bhattacharyya SK, Singh B. High performance materials and construction technologies for sustainable built space. Supra Institutional Project Report (SIP 29), CSIR-Central Building Research Institute, Roorkee, India; 2012.

44. Singh B, Sharma S, Gupta M, Bhattacharyya SK. Performance of fly ash-based geopolymer pastes under chemical environment. In: International conference on advances in construction materials through science and engineering, Hong Kong; 5-7 September, 2011.

45. Rajamane NP, Natraja MC, Dattatreya JK, Lakshmanan N, Sabitha D. Sulphate resistance and eco-friendliness of geopolymer concretes. Ind Concr J 2012; 86:13-21.

46. Bernal SA, Gutierrez RM, Provis JL. Engineering and durability properties of concrete based on alkali-activated granulated blast furnace slag/metakaolin blends. Constr Build Mater 2012; 33:99-108.

47. Reddy DV, Edouard JB, Sobhan K, Tipni A. Experimental evaluation of the durability of fly ash-based geopolymer concrete in the marine environment. In: 9th Latin American and Caribbean conference on engineering for a smart planet, innovation, information technology and computational tools for sustainable development Colombia, Australia; 2011.

48. Singh B, Gupta M, Chauhan M, Bhattacharyya SK. Lightweight geopolymer concrete with EPS. In: CIB World Building Congress 2013, Brisbane, Australia; 5-9 May, 2013. 
49. P. Alagarsamy, G.N. Krishnan, S.M. Chen, T. Kokulnathan, T.W. Chen, N. Raja, X. Liu, I.S. Hong and V. Selvam, Int. J. Electrochem. Sci., 12 (2017) 6842.

50. Laskar AI, Bhattacharjee R. Rheology of fly ashbased geopolymer concrete. ACI Mater J 2011; 108:536-42.

51. Montes C, Allouche EN. Rheological behaviour of fly ash-based geopolymers. STP 1566 on Geopolymer Binder Systems 2013, ASTM: p. 7284.

52. Olivia M, Nikraz H. Properties of fly ash geopolymer concrete designed by taguchi method. Mater Des 2012; 36:191-8.

53. Singh A. Engineering properties of reinforced geopolymer concrete [B. Tech project report]. Roorkee, India. CSIR-Central Building Research Institute; 2012.

54. Diaz-Loya EI, Allouche EN, Vaidya S. Mechanical properties of fly ash-based geopolymer concrete. ACI Mater J 2011; 108:300-6.

55. Ryu GS, Lee YB, Koh KT, Chung YS. The mechanical properties of fly ash-based geopolymer concrete with alkaline activators. Constr Build Mater 2013; 47:409-18.

56. Bondar D, Lynsdale CY, Milestone NB, Hassani $\mathrm{N}$, Ramezanianpour AA. Engineering properties of alkali-activated natural pozzolan concrete. ACI Mater J 2011; 108:64-72.

57. Yost JR, Radlinska A, Ernst S, Salera M. Structural behavior of alkali activated fly ash concrete. Part 1: mixture design, material properties and sample fabrication. Mater Struct 2012; 46:435-47.

58. Pan Z, Sanjayan JG, Rangan BV. Fracture properties of geopolymer paste and concrete. Mag Concr Res 2011; 63:763-77.

59. Sarker PK, Haque R, Ramgolam KV. Fracture properties of heat cured fly ash-based geopolymer concrete. Mater Des 2013; 44:580-6.

60. Demie S, Nuruddin MF, Shafiq N. Effects of micro-structure characteristics of interfacial transition zone on the compressive strength of self-compacting geopolymer concrete. Constr Build Mater 2013; 41:91-8.
61. ACI 408R-03. Bond and development of straight reinforcing bars in tension.

62. Sarker PK. Bond strength of reinforcing steel embedded in fly ash-based geopolymer concrete. Mater Struct 2011;44:1021-30

63. P. Parameswaran, A. Godwin Antony, S. Dinesh, K. Radhakrishnan, Experimental study on mechanical and corrosion characteristics of nab alloy with the addition of chromium, Materials Today: Proceedings, Volume 5, Issue 2, Part 2, 2018, Pages 8089-8094, ISSN 22147853,https://doi.org/10.1016/j.matpr.2017.11.495.

64. Rameshbabu, A., Parameswaran, P., Vijayan, V., et al. (2017). Diffraction, microstructure and thermal stability analysis in a double phase nanocrystalline A120Mg20Ni20Cr20Ti20 high entropy alloy. Journal of the Mechanical Behavior of Materials, 26(3-4), pp. 127-132. Retrieved 14 Nov. 2018, from doi:10.1515/jmbm-2017-0021

65. Parameswaran, P \& Rameshbabu, A.M. \& Navaneetha Krishnan, G \& Yogeshwaran, R \& Ramkumar, R. (2018). Study of the corrosion properties in a hot forged $\mathrm{Cu}-\mathrm{Al}-\mathrm{Ni}$ alloy with added Cr. Journal of the Mechanical Behavior of Materials. 27. 10.1515/jmbm-2018-0016.

66. P. Sakthivel, G. Arunkumar , P. Navaneetha Krishnan , R. Ramkumar and P. Parameswaran (2018), Experimental Heat Transfer Analysis on Heat Pipe using Sio2 and Tio2 Nano Fluid, Journal of Applied Fluid Mechanics, Vol. 11, Special Issue, pp. 91-101, 2018. ISSN 1735-3572, EISSN 1735-3645.

67. Dinesh S, Godwin Antony A, K.Rajaguru, V.Vijayan," Experimental Investigation and Optimization of Material Removal Rate and Surface Roughness in Centerless grinding of Magnesium Alloy using Grey Relational Analysis", Mechanics and Mechanical Engineering, Vol 21, No 1 (2017), pp.no 17-28.

68. Godwin Antony A, Aravind S, Dinesh S, K.Rajaguru, V. Vijayan," Analysis and Optimization of Performance Parameters in Computerized IC Engine Using Diesel Blended with Linseed Oil and Leishmaan's Solution", Mechanics and Mechanical Engineering, Vol 21 issue 2, pp.no 193-205.

69. Dinesh S, Prabhakaran M, Godwin Antony A, K. Rajaguru, V. Vijayan,'Investigation and Optimization of Machining Parameters in 
Processing AISI 4340 Alloy Steel with Electric Discharge Machining", International Journal of Pure and Applied Mathematics, Vol 117 No. 16 2017, 385-391.

70. Dinesh S, Godwin Antony A, K. Rajaguru, V. Vijayan,"Comprehensive Analysis of Wire Electric Discharge Machining Process in Machining High Chromium High Carbon Steel", International Journal of Mechanical and Production Engineering Research and Development Vol. 8, No 1, Feb 2018, 65-74.

71. A. M. Rameshbabu, P. Parameshwaran, V. Vijayan, R.Panner, 2017, Diffraction, microstructure and thermal stability analysis in a double phase nanocrystalline Al20Mg20Ni20Cr20Ti20 high entropy alloy, Journal of Mechanical behavior and materials, vol.26, Issue 3-4, pp.127-132 (Scopus Indexed Journal).

72. R. Srinivasan, V. Vijayan, K. Sridhar, 2017, Computational Fluid Dynamic Analysis of Missile with Grid Fins, Journal of applied Fluid Mechanics, vol.10, Special Issue, pp.33-39 (SCIE Indexed Journal).

73. R. Venkatesh, V. Vijayan, 2016, Performance Evaluation of Multipurpose Solar Heating System, Mechanics and Mechanical Engineering, vol.20, no.4, pp.359-370(Scopus Indexed Impact factor: 0.11 )

74. Rajkumar T., Karuppusamy S., Vijayan V., 2016, Testing of Mechanical Properties of Hybrid Fiber Reinforced Composites, Asian Journal of Research in Social Sciences and Humanities, Vol. 6, No. 10, pp 213- 225.

75. B. Suresh Kumar, V. Vijayan, N. Baskar, , ' Optimization of Drilling Process Parameters for Material Removal Rate and Surface Roughness on Titanium Alloy using Response Surface Methodology and Fire Fly Algorithm', Asian Journal of Research in Social Sciences and Humanities,, Vol. 6, No. 5, May 2016, pp.12511267. 